\title{
A Novel Stability Study of Simvastatin Generic Tablet in Public Pharmacy Facilities of Purwakarta, Indonesia
}

\author{
Rini Yulianita1, Iyan Sopyan², Amirah Mohd Gazzali³, Muchtaridi Muchtaridi 1*
}

1. Department of Pharmaceutical Analysis and Medicinal Chemistry, Faculty of Pharmacy, Universitas Padjadjaran, Bandung, Indonesia

2. Department of Pharmaceutics and Pharmaceutical Technology, Faculty of Pharmacy, Universitas Padjadjaran, Bandung, Indonesia

3. School of Pharmaceutical Sciences, Universiti Sains Malaysia, 11800 USM Penang, Malaysia

\begin{abstract}
Info Article
Submitted: 06-10-2021

Revised: 09-12-2021

Accepted: $18-12-2021$

*Corresponding author

Muchtaridi Muchtaridi

Email:

muchtaridi@unpad.ac.id

ABSTRACT

Drug stability is one of the most important criteria for producing safe, excellent, and effective products. Some environmental factors that influence drug stability are light, temperature, and humidity. Simvastatin is a cholesterol-lowering drug that is known to be sensitive to high temperatures and humidity. The purpose of this study is to analyze the effect of 6 months of real-time storage conditions on the stability of generic simvastatin tablets in public pharmacy facilities. This study used a simulation method with 4 brands of simvastatin generic tablets with two different strengths $(10 \mathrm{mg}$ and $20 \mathrm{mg}$ ). In the process, the sample was conditioned in 6 different regions for 6 months. The results of temperature and humidity monitoring showed 2 locations at $\leq 25^{\circ} \mathrm{C}, 4$ locations had a temperature of $\geq 25^{\circ} \mathrm{C}$ and all locations had humidity $>65 \%$. The drug was evaluated for physical and chemical quality parameters at months 0,3 , and 6 . After being stored for 6 months, the tablets showed a decrease in disintegration time and an increase in friability, showing a lack of durability. Similarly, there was a decrease in the content concentration in the tablets but fortunately, the level was still within the accepted specification range (90 - $110 \%)$. However, there was one tablet that did not meet the dissolution test requirements after the storage duration $(\mathrm{Q} \leq 75 \%$ at $30 \mathrm{~min})$. The results of the stress test showed that simvastatin degraded in all conditions. This stress test confirmed the extreme instability of simvastatin. Poor storage conditions can reduce the quality of generic simvastatin tablets, thus a well-controlled environment is vital in pharmacy facilities.
\end{abstract}

Keywords: Drug stability, simvastatin, storage conditions, pharmacy facilities

\section{INTRODUCTION}

Drug stability can be defined as the durability and efficacy of a product within the prescribed limit of storage and use period, to maintain the same traits and characteristics possessed at the time of packaging (Allen, 2013; Melo et al., 2014; Tembhare et al., 2019). Environmental factors such as temperature, light, radiation, air (especially oxygen and carbon dioxide), and humidity may have a detrimental effect on the stability of a particular product (World Health \& Preparations, 2018a). If the storage can be controlled to be within the conditions as recommended by the manufacturer, the proposed shelf life would ascertain the stability of the active ingredient and subsequently the effectiveness of the drugs (Bajaj et al., 2012; Tembhare et al., 2019).

A previous study reported on the alteration of dissolution property of sodium diclofenac tablets following storage under simulated conditions of tropical climate in Congo (Mubengayi et al., 2016). In Yemen, it was found that $80 \%$ of amoxicillinclavulanic acid products were substandard and did not meet the requirements outlined by USP30 (Othman \& Al-qadasi, 2016). A study in Australia reported that the characteristics of products stored in tropical conditions changed, with the presence of microbial contamination during the manufacturing 
or repackaging process (Raman, 2017). In Brazil, the release of mefloquine from the tablets was affected by improper storage conditions (Nogueira et al., 2011). Based on these findings, the storage condition of pharmaceutical products is very important, especially for drugs that are easily oxidized, thermolabile, or sensitive to moisture (World Health \& Preparations, 2018b). Thus, environmental control in pharmacies needs to be ensured, to prevent degradation of products during storage throughout the proposed shelf life (BIO Intelligence Service, 2013; Shafaat et al., 2013).

Simvastatin is a cholesterol-lowering drug that is known to be sensitive to temperature (Jemal et al., 2000) and susceptible to humidity (Chen et al., 2012). The required storage conditions for simvastatin are a temperature of between $20^{\circ}$ to $25^{\circ} \mathrm{C}\left(68^{\circ}\right.$ to $\left.77^{\circ} \mathrm{F}\right)$ in a tight container and protected from moisture (USP, 2006). In this study, stability tests with stress tests for simvastatin was carried out, including stability in hydrolytic acid conditions (Lotfy et al., 2010), in combination with ezetimibe (Devu et al., 2012), sitaglipine (Ramalingam et al., 2014) and ramipril/aspirin (Kapuganti et al., 2016).

In related studies conducted in Brazil, only 14 out of 30 batches of simvastatin 20 mg capsules met the pharmacopeia quality standards, and 6 out of 18 samples of simvastatin $40 \mathrm{mg}$ capsules had lower than expected concentration of simvastatin, between 4-87\% (Markman et al., 2010). Furthermore, research in Indonesia showed that 1 in 2 generic simvastatin drugs did not meet the requirements (less than 90\%) (Hapsari, 2016). Many stability studies were carried out in laboratories under controlled temperature and humidity conditions. Even though in actual conditions, the product will be exposed to various environmental factors before they reach the patients. Many experienced pharmaceutical scientists believed that the field stability study will give useful information (Ammann, 2011). The use of simvastatin for the treatment of dyslipidemia is usually a lifelong treatment (Eiland \& Luttrell, 2010). Therefore, it is important to evaluate the stability of the available simvastatin-containing products in the market to ensure the efficacy, safety, and quality of the drugs received by patients. The novelty of this study was the effect of 6 months of real-time storage conditions on the stability of generic simvastatin tablets in public pharmacy facilities.

\section{MATERIAL AND METHODS}

The materials used in this study were acetonitrile gradient grade for liquid chromatography (JT Baker, USA), methanol HPLCgrade (Sigma, USA), methanol analytical-grade (Merck, Germany), aquabidest (PT. Ikapharmindo Putramas, Indonesia), sodium lauryl sulfate (Sigma, USA), sodium phosphate monobasic (Merck, Germany), sodium hydroxide (Merck, Germany), ammonium acetate (Sinopharm Chemical Reagent, China), glacial acetic acid (Merck, Germany), simvastatin Working Standard (TEVA Pharmaceutical, Hungary), generic simvastatin tablets $10 \mathrm{mg}$ and $20 \mathrm{mg}$.

\section{Sampling}

This study was designed with a simulation method in which simvastatin generic tablets were obtained from distributors simultaneously, to have a standard initial time $=0$. A specified number of tablets (180 tablets per brand) were sent to the allocated storage locations and the rest that tested directly to obtain the time $=0$ characteristics and data. The tablets were kept in an uncontrolled drug room at six public pharmacy facilities. The actual temperature and humidity were recorded every day for 6 months. The location was selected based on topography such as mountainous, hills and lakes, and lowlands at two locations in each area. Sampling was carried out at months 0,3 , and 6 based on the stability's protocol that had been reported elsewhere (FDA, 2005) (Figure 1).

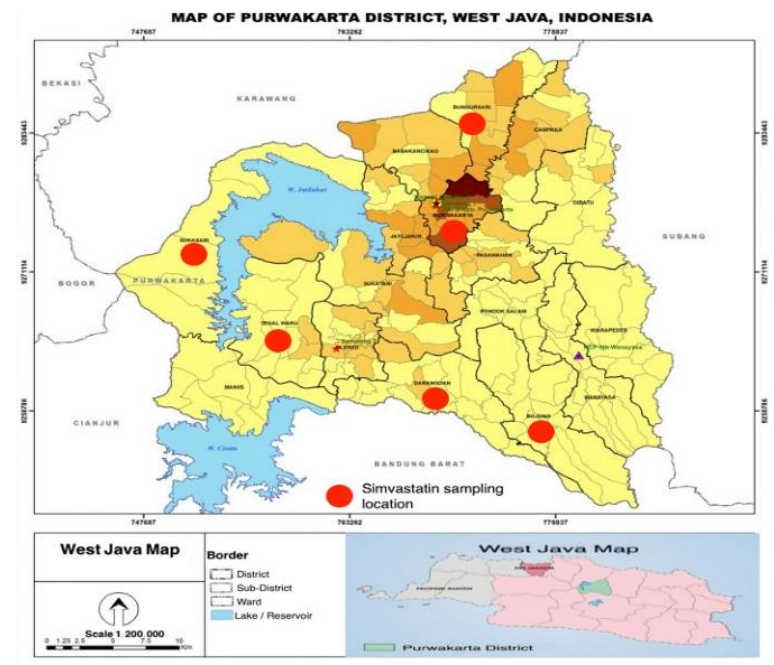

Figure 1. Purwakarta District map showing the location of the selected wards (red bullet) 


\section{Physical examination}

Tablet examination was done by visual inspection. Each sample was examined based on shape, size, color, and packaging, and the physical appearance of the tablets was observed. Smooth, undamaged, and uniformLy colored tablets were included in the study.

\section{Friability tablet}

Tablet friability was tested using the friability tester (Varian Friabilator, Varian Inc., USA). At each time point, 20 clean tablets from each storage locations were weighed (Ohaus Pioneer, Ohaus Corp., USA) and the weight was recorded $( \pm 4 \mathrm{~g})$. The tablets were placed inside the friability tester $($ speed $=25 \mathrm{rpm}$. Time $=4 \mathrm{~min})$. After the designated testing time, the tablets were cleaned from any dust, weighed (y gram) and the percentage of weight loss was calculated $(n=3)$ (Farmakope, 2014).

\section{Tablet hardness}

Tablet hardness was checked by a hardness tester (Erweka, Erweka GmbH, Germany). One tablet is placed in an upright position in the durability tester machine, and the button was pressed until the tablet shattered. The scale reading on the instrument showed the tablet hardness in Kgf. The test was carried out on 20 tablets from each storage location (Farmakope, 2014).

\section{Disintegration time}

The tablet disintegration test was conducted using a USP disintegration tester Type 2 (Sotax AT7 Smart Dissolution Tester, Sotax AG, Switzerland). Six tablets were placed in a crushed test basket containing water at $37 \pm 1^{\circ} \mathrm{C}(1000 \mathrm{~mL})$. The basket was set to go up and down regularly for 30 times per minute. The tablets were considered to be fully disintegrated if there was no part of the tablet left in the gauze, except for the coating material. The test was conducted on 6 tablets from each storage location at each time point $(n=3)$ (Farmakope, 2014).

\section{Verification of analytical methods HPLC Methods}

The HPLC methods was adopted from Karbane et al. with some modifications following verification of the validation parameters (selectivity, linearity, accuracy, precision, and System Suitability (Karbane et al., 2014).

\section{Selectivity}

Selectivity was conducted by looking at the single simvastatin chromatogram peak without the present of any other peaks in the analysis of powdered tablets with excipients. A specified quantity of tablet powders equivalent to simvastatin $10 \mathrm{mg}$ were dissolved in a $50 \mathrm{~mL}$ volumetric flask and diluted with methanol until $50 \mathrm{~mL}$. $1.0 \mathrm{~mL}$ of the solution was pipetted into a 10 $\mathrm{mL}$ volumetric flask, filled with methanol and filtered with a $0.2 \mu \mathrm{m}-0.45 \mu \mathrm{m}$ syringe filter. The sample was then injected into the HPLC system (ICH, 2005).

\section{Linearity}

Five concentrations of simvastatin standard solution $(5,10,15,20$, and $25 \mathrm{~g} / \mathrm{mL})$ were prepared by making a serial dilution of simvastatin stock solution $1 \mathrm{mg} / \mathrm{mL}$ in methanol. All solutions were filtered using $0.2 \mu \mathrm{m}-0.45 \mu \mathrm{m}$ syringe filter prior to injection into the HPLC system (ICH, 2005).

\section{Accuracy and precision}

Accuracy and precision were determine based on the ability of the system to analyze 3 samples at different concentrations, prepared within the concentration of the standard curve range; low concentration $8 \mathrm{~g} / \mathrm{mL}(80 \%)$, medium concentration $10 \mathrm{~g} / \mathrm{mL} \quad(100 \%)$ and high concentration $12 \mathrm{~g} / \mathrm{mL}$ (120\%). Accuracy was determined by the simulation method; a number of pure standards were added to the tablet powder equivalent to $10 \mathrm{mg}$ of simvastatin then the mixture was analyzed and the results were compared with the levels of the added pure standard. Precision is measured by the relative standard deviation of the repeated assays on the samples (ICH, 2005).

\section{System suitability test}

The system suitability test was carried out by injecting a standard solution of simvastatin with a concentration of $20 \mathrm{~g} / \mathrm{mL}$ for six times using HPLC with an injection volume of $10 \mu \mathrm{L}$. The coefficient of variations $(\mathrm{kV})$ for the retention time, area and peak asymmetry were then determined from the chromatograms obtained, to evaluate the repeatability of the injection (USP, 2017b).

\section{UV Methods}

The UV analysis was done based on the method described by Kulkarni et al. (Kulkarni et al., 2012) and Marques-Marinho et al. (MarquesMarinho et al., 2011). The validation of the method was conducted as below. 


\section{Selectivity}

Selectivity was done by looking at the comparison of the absorption curve of pure simvastatin and simvastatin in powdered tablet. One tablet which is equivalent to $10 \mathrm{mg}$ simvastatin was transferred to a flask containing $900 \mathrm{~mL}$ of dissolution medium (0.01 M phosphate buffer with $0.5 \%$ SDS) and stirred at $37^{\circ} \mathrm{C}$ for $30 \mathrm{~min}$ at $50 \mathrm{rpm}$ using a paddle. Aliquots $(10 \mathrm{~mL})$ of the solution were filtered through Whatman filter paper No. 41 and analyzed by UV-Vis spectrophotometry method at $238 \mathrm{~nm}(\mathrm{n}=3)$ (USP, 2012).

\section{Linearity}

Calibration curves were made with simvastatin standard solutions with concentrations of $4,6,8,10$, and $12 \mathrm{~g} / \mathrm{mL}$ in dissolution medium $(0.01 \mathrm{M}$ phosphate buffer with $0.5 \%$ SDS) and the absorbance was measured using a UV-Vis spectrophotometer at $238 \mathrm{~nm}(\mathrm{n}=3)$ (USP, 2011).

\section{Accuracy and precision}

The simvastatin standard was added to the dissolution flask in known amounts at concentrations of $80 \%, 100 \%$, and $120 \%$. One tablet equivalent to simvastatin $10 \mathrm{mg}$ was added to each flask containing the standard $(900 \mathrm{~mL}$, $\left.37 \pm 0.5^{\circ} \mathrm{C}\right)$. The dissolution test was carried out for $30 \mathrm{~min}$ at $50 \mathrm{rpm}$ using a paddle. Aliquots were filtered through Whatman filter paper No. 41 and analyzed by UV spectrophotometry at $238 \mathrm{~nm}$ $(\mathrm{n}=3)$ (USP, 2011).

\section{Assay content}

The assay on the tablet content was done by a RP-HPLC equipped with UV - Vis detectors (Dionex Ultimate 3000, Dionex Corp., USA) and C18 column (Shodex C18, $460 \mathrm{~mm}$ x $250 \mathrm{~mm}$, Showa Denko America Inc., USA). 20 tablets of simvastatin were weighed, and the average weight was determined. The tablets were then crushed using mortar and pestle until a smooth powder was obtained. The tablet powder was weighed according to the average weight and mixed with methanol in a $50 \mathrm{~mL}$ volumetric flask. The sample solution was further diluted with methanol to obtain a final simvastatin concentration of 20 $\mu \mathrm{g} / \mathrm{mL}$. The sample $(10 \mathrm{~mL})$ was then filtered with a $0.45 \mu \mathrm{m}$ nylon filter membrane (CNW Technologies, CNW Technologies GmbH, Germany) and analyzed at $240 \mathrm{~nm}$, with a mobile phase constituted of acetonitrile: ammonium acetate buffer pH $3=90: 10$ and a flow rate of $1.0 \mathrm{~mL} / \mathrm{min}$ (Kumar et al., 2009).

\section{Dissolution}

The dissolution test was carried out using a USP dissolution tester Type 2 (Sotax AT7 Smart Dissolution Tester, Sotax AG, Switzerland) with rowing method (50 rpm) for $30 \mathrm{~min}$ in $900 \mathrm{~mL}$ of $0.01 \mathrm{M}$ phosphate buffer with $0.5 \%$ SDS. Six tablets were used, in which one tablet was placed in each vessel. The drawn aliquots (without media replacement) were filtered with Whatman paper No. 41 and their absorption was measured by UVVis spectrophotometer (Specord 205, Analytik Jena $\mathrm{GmbH}$, Germany) at $238 \mathrm{~nm}$.

\section{Statistical analysis}

Data processing was carried out statistically using the comparative multivariate ANOVA method with SPSS 16.0 software. Multivariate ANOVA comparative test was performed at the $95 \%$ confidence level $(\mathrm{p} \leq 0.05)$.

\section{RESULT AND DISCUSSION \\ Tablet Physical Examination}

This study analyzed $10 \mathrm{mg}$ and $20 \mathrm{mg}$ simvastatin generic tablets based on the 2017 and 2018 e-catalogues (Table I). The evaluation of the physical appearance of the tested tablets involve measuring the size, shape, tablet color, presence or absence of odor, taste, surface texture, physical weakness and consistency, and readability of identification marks (Seitz \& Flessland, 1965). The physical properties of generic simvastatin tablets were evaluated by visual inspection. Physical examination of 4 samples of generic simvastatin tablets at month 0 showed good tablet conditions, uniformed color and no tablets were cracked, or damaged. The tablet samples were then sent to the allocated storage locations, and their physical appearance was re-observed after 3 months.

In general, all tablets showed good physical appearance throughout the storage duration. Only one tablet (SIM K20) showed chipping and this is probably due to the absence of coating layer, as the other 3 tablet samples were film-coated. The coating layer protects the tablets from the surrounding environment and prevent chipping, breaking or other physical damages during transportation and storage (Waterman \& MacDonald, 2010). 
Table I. Simvastatin tablets from 2017 and 2018 e-catalogues.

\begin{tabular}{ccccc}
\hline Sample Name & Sample Code & Packaging type & Batch No & Expiry Date \\
\hline Simvastatin T 20 mg & SIM T20 & Strip & 023558 & February 2020 \\
Simvastatin K 20 mg & SIM K20 & Strip & B80278B & February 2021 \\
Simvastatin Y 10 mg & SIM Y10 & Blister & A8751 & June 2020 \\
Simvastatin D 10 mg & SIM D10 & Blister & $49 F 0173$ & May 2020 \\
\hline
\end{tabular}

\section{Friability tablet}

Tablets must withstand mechanical shocks during manufacturing process, packaging, and distribution. The friability test is one of the important test in the quality assurance of tablets to measure tablet resistance to abrasion or fracture. The idea behind this test was to imitate the type of potency which is caused by phenomena such as collisions and sliding of tablets during coating, packaging, handling, and shipping. Conventional compact tablet that loses weight between $0.5-1.0$ $\%$ is generally considered acceptable (Gupta \& Gupta, 2016; USP, 2011).

The friability of tablets was tested on the four samples evaluated. The results showed that SIM K20 recorded the highest tablets weight loss, most probably due to the uncoated tablet formulation. In addition, SIM K20 tablets were also fragile on handling upon removal from the primary packaging. The other three samples met the friability requirements throughout the six-month storage period.

As friability is related to tablet hardness, care should be in place during the formulation process. The hardness of a tablet could be altered during storage due to moist absorption, leading to a reduction in tablet hardness over time. This effect is especially important in non-coated tablets, because softer tablets would be generally more fragile and difficult to be handled by patients (Waterman \& MacDonald, 2010).

\section{Tablet hardness}

Tablet hardness served as a criterion to guide product development and quality control specification. A tablet should not be too hard or too soft. A very hard tablet has the potential for excessive bonding between active ingredient(s) and excipients, which would affect the dissolution. In the same way, softer tablets could be the result of weak bonds and could cause premature disintegration following consumption. Soft tablets could also interfere with the processing stages in manufacturing, such as coating and packaging (Chiang, 2013). According to the pharmacopeias, tablet hardness must be between 5 and $10 \mathrm{kgf}$ (Chaturvedi et al., 2017). A tablet with a hardness of less than $4 \mathrm{kgf}$ can be accepted if its friability meets the requirements. The hardness of tablets greater than $10 \mathrm{kgf}$ is still acceptable if it meet the requirements of disintegration time and dissolution (USP, 2011).

Based on this study, samples stored for 6 months showed a reduction in hardness compared to the initial test. The greatest reduction occurred in SIM Y10 (7-8 kgf to 4-5 kgf) and SIM D10 (12-13 Kgf to 9-10 Kgf). Tablet hardness was reduced due to the high humidity ( $>65 \%$ ) during storage. As a result, the tablets appeared sticky and brittle. The samples with the greatest reduction in hardness were packed in blister packaging. The blister forming component commonly used was polyvinyl chloride (PVC) as film and aluminum forming material as cover material. The advantages of PVC are cheap and easily formed through thermoforming. However, the main disadvantage of PVC is poor resistance towards oxygen and moisture, and it is also unsuitable for drugs that are sensitive to light because they are transparent. Also, PVC has negative environmental connotations due to the toxic chlorine content. Strips formed from aluminum are good barrier to moisture and oxygen. It provides an economical packaging solution for highly sensitive drugs and it is a perfect pharmaceutical packaging material for drug protection and distribution (Singh et al., 2011). In a study by Akbuga (1987), it was reported that there was a two-fold reduction in the hardness of tablets stored at room temperature and $75 \% \mathrm{RH}$ in 4 days, whilst there was no significant changes in the tablet hardness stored at ambient temperature and ambient humidity in 20 days (Akbuga \& Gürsoy, 1987). In another study, the hardness of the tested tablets was reduced, and the friability was increase following storage for six months in $75 \% \mathrm{RH}$ at different temperatures: $25^{\circ} \mathrm{C}$ (hardness reduction: $5-10 \%$ ) and $45^{\circ} \mathrm{C}$ (hardness reduction: $10-39 \%)$. The results showed that moisture absorption by the tablet matrix will affect their hardness and friability (Ahmad \& Shaikh, 1994). 


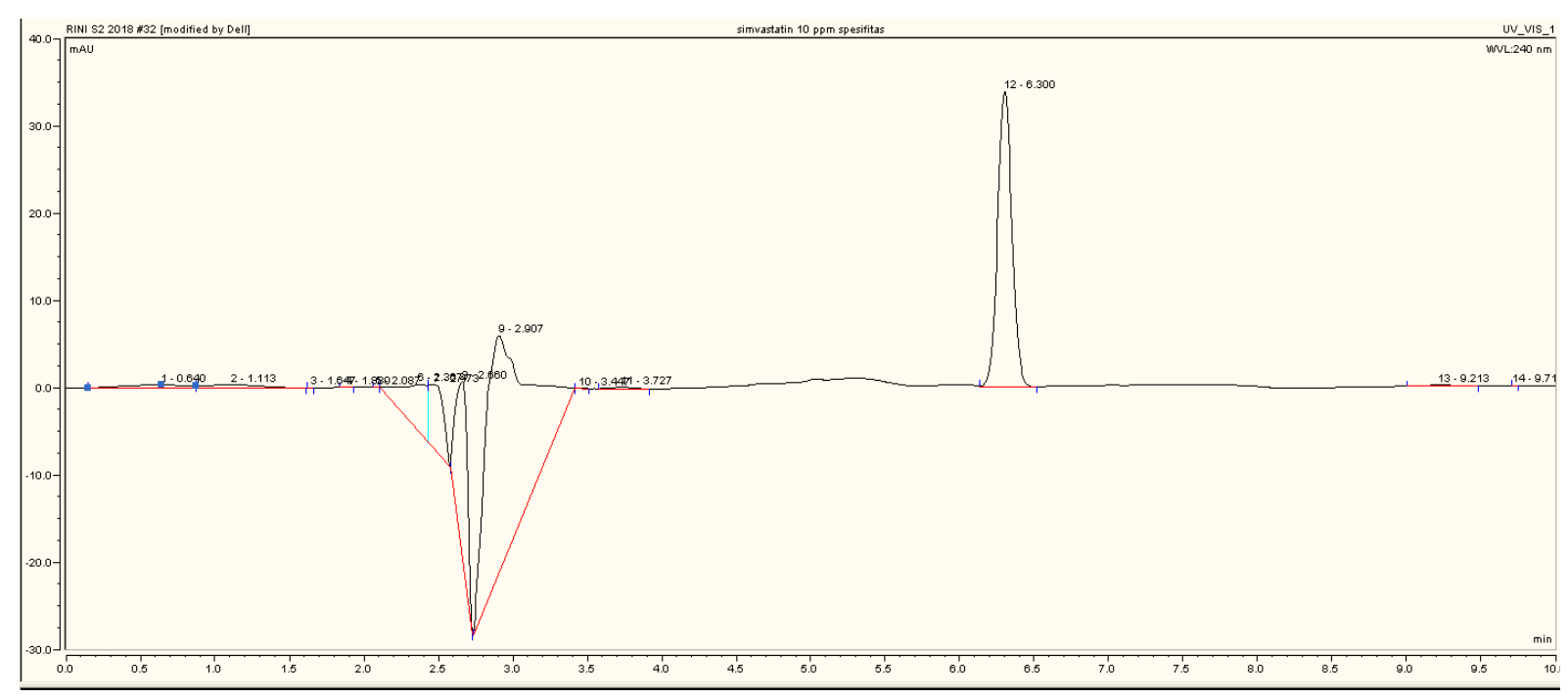

Figure 2. Specificity Test Chromatogram.

Table II. System Suitability Test

\begin{tabular}{ccccc}
\hline $\begin{array}{c}\text { Sample Concentration } \\
\text { (ppm) }\end{array}$ & AUC & $\begin{array}{c}\text { Retention } \\
\text { Time }\end{array}$ & $\begin{array}{c}\text { Asymmetry } \\
\text { Factor }\end{array}$ & $\begin{array}{c}\text { Theoretical Plate } \\
\text { Number }\end{array}$ \\
\hline 20 & 77204 & 6.347 & 1.04 & 20235 \\
20 & 76706 & 6.260 & 1.05 & 20266 \\
20 & 76866 & 6.260 & 1.03 & 20201 \\
20 & 76299 & 6,287 & 1.03 & 20114 \\
20 & 76680 & 6.287 & 1.03 & 20179 \\
20 & 76516 & 6.293 & 1.06 & 20222 \\
RSD & 0.40 & 0.51 & 1.22 & 0.26 \\
\hline
\end{tabular}

Dugar et al. examined the hardness values of acetaminophen tablets for all batches following exposure to different humidity. The tablet hardness showed a negative correlation with humidity whereby a higher humidity was found to decrease the hardness of tablets (Dugar et al., 2015).

\section{Disintegration time}

Disintegration time is a physical process that is associated with tablet mechanical splitting into smaller particles or granules. It refers to interparticle interaction splitting that is generated during tablet compaction from particles or granules of active pharmaceutical ingredient(s) (API) and excipients (Markl \& Zeitler, 2017). In general, after the liquid has wetted the tablet surface and penetrated the pores, disintegration occurs in two steps: firstly, the disintegration of the tablets into smaller particles, and secondly, disaggregation or disintegration of the particles or granules (Rubinstein \& Bodey, 1976). The United
States Pharmacopeia (USP) has set a disintegration test time limit for 15 min for non-coated tablets and 30 min for film-coated tablet (Farmakope, 2014). The four samples of simvastatin tablets tested showed different disintegration profiles. SIM K20 tablet had the longest disintegration time despite being uncoated, thus this could be influenced by the tablet formulation itself.

All simvastatin tablets tested met the pharmacopeia's standard on disintegration time throughout the six-month duration. However, there is a notable reduction in the disintegration time, perhaps due to the reduction in tablet hardness during storage, as explained earlier. A study by Gbenga et al (2016) on paracetamol tablets stored in stability chambers at different RH \% (23\%, 43\%, $83 \%, 86 \%$, and $93 \%$ ) for 2 months showed a significant reduction in disintegration time with increasing $\mathrm{RH} \%$. Paracetamol tablets exposed to $93 \%$ RH showed the greatest reduction in hardness and disintegration time (Bakre \& Taiwo, 2015). 


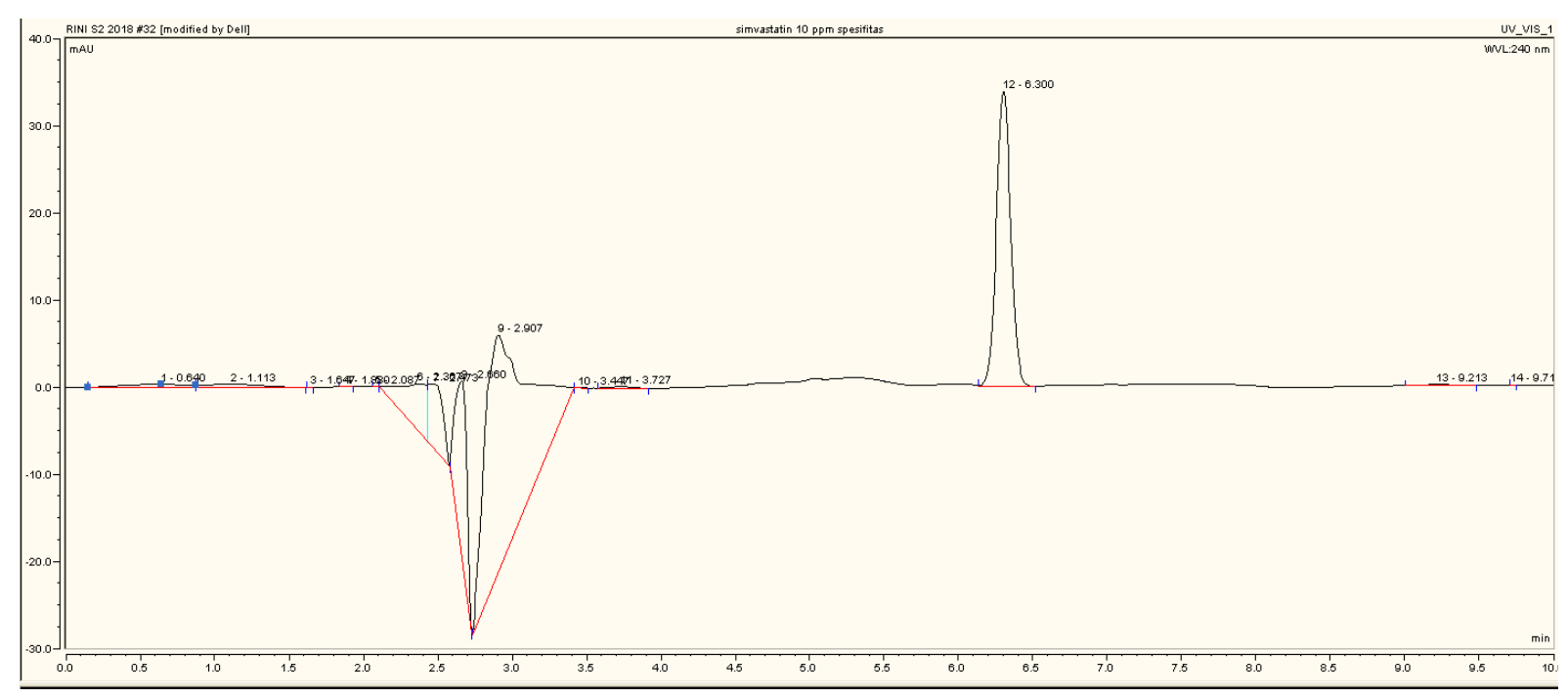

Figure 2. Specificity Test Chromatogram.

Table II. System Suitability Test

\begin{tabular}{ccccc}
\hline $\begin{array}{c}\text { Sample Concentration } \\
\text { (ppm) }\end{array}$ & AUC & $\begin{array}{c}\text { Retention } \\
\text { Time }\end{array}$ & $\begin{array}{c}\text { Asymmetry } \\
\text { Factor }\end{array}$ & $\begin{array}{c}\text { Theoretical Plate } \\
\text { Number }\end{array}$ \\
\hline 20 & 77204 & 6.347 & 1.04 & 20235 \\
20 & 76706 & 6.260 & 1.05 & 20266 \\
20 & 76866 & 6.260 & 1.03 & 20201 \\
20 & 76299 & 6,287 & 1.03 & 20114 \\
20 & 76680 & 6.287 & 1.03 & 20179 \\
20 & 76516 & 6.293 & 1.06 & 20222 \\
RSD & 0.40 & 0.51 & 1.22 & 0.26 \\
\hline
\end{tabular}

\section{HPLC Methods}

\section{Selectivity (Specificity)}

The results of the specificity test showed that in a single simvastatin chromatogram, there was no interference from the tablet matrix when compared to a pure standard simvastatin chromatogram (Figure 2).

\section{Linearity}

The correlation coefficient 0.99 is generally considered as evidence of the suitability of the data with the regression line (EMA, 1995; Shabir, 2003). The equation of the line obtained is $\mathrm{y}=0.3628 \mathrm{x}+$ 0.2678 with $r^{2}=0.9995$. This indicates that the linearity of this method has met the specifications.

\section{Accuracy and precision}

Accuracy criteria for the test method are the average percentage recovery of $100 \pm 2 \%$ at each concentration in the range of $80-120 \%$ of the target concentration. The precision criterion for the test method was found to be $2 \%$. From the results of accuracy and precision testing, the average simvastatin level was $100.35-100.91 \%$ with RSD $0.21-0.88 \%$. The accuracy and precision of this method still meet the established criteria.

\section{System suitability test}

According to Pharmacopoeia V, the parameters that must be met for the assay of simvastatin tablets are column efficiency of not less than 4500 theoretical plates, follow-up factor of not more than 2.0, and standard deviation at reinjection of not more than 2.0\% (EMA, 1995; FDA, 2015). The system suitability test shows that all parameters meet the specifications so that it can be stated that the system in this method is suitable and adequate for analysis (Table II). 
Table IIIa. Stability study of simvastatin generic tablets after six months

\begin{tabular}{|c|c|c|c|c|c|c|c|}
\hline \multirow[b]{2}{*}{ Location } & \multirow[b]{2}{*}{$\begin{array}{c}\text { Tablet } \\
\text { code }\end{array}$} & \multirow[b]{2}{*}{$\begin{array}{c}\text { Storage } \\
\text { Condition }\end{array}$} & \multicolumn{5}{|c|}{ Parameter } \\
\hline & & & $\begin{array}{c}\text { Friability } \\
\text { (\%) }\end{array}$ & $\begin{array}{l}\text { Hardness } \\
\text { (kgf) }\end{array}$ & $\begin{array}{c}\text { Disintegration } \\
\text { time (min) }\end{array}$ & $\begin{array}{c}\text { Dissolution } \\
\text { (\%) }\end{array}$ & $\begin{array}{l}\text { Simvastatin } \\
\text { content }(\%)\end{array}$ \\
\hline \multirow{10}{*}{$\begin{array}{c}\text { Mountaneous } \\
\text { A }\end{array}$} & \multirow{3}{*}{$\mathrm{T} 20$} & Initial & $0.14 \pm 0.01$ & $7.28 \pm 0.36$ & $0.54 \pm 0.03$ & $99.03 \pm 2.93$ & $101.46 \pm 1.62$ \\
\hline & & 3 month & $0.15 \pm 0.03$ & $7.25 \pm 0.46$ & $0.52 \pm 0.03$ & $97.71 \pm 2.22$ & $100.99 \pm 0.83$ \\
\hline & & 6 month & $0.20 \pm 0.01$ & $7.24 \pm 0.76$ & $0.48 \pm 0.02$ & $94.47 \pm 2.37$ & $95.97 \pm 0.22$ \\
\hline & \multirow{3}{*}{ K20 } & Initial & $0.15 \pm 0.02$ & $4.73 \pm 0.31$ & $7.57 \pm 0.80$ & $74.35 \pm 6.99$ & $99.97 \pm 1.19$ \\
\hline & & 3 month & $0.24 \pm 0.01$ & $4.33 \pm 0.40$ & $7.08 \pm 0.41$ & $70.88 \pm 3.61$ & $99.78 \pm 0.69$ \\
\hline & & 6 month & $0.31 \pm 0.05$ & $4.26 \pm 0.37$ & $6.96 \pm 0.15$ & $60.73 \pm 3.63$ & $93.05 \pm 0.42$ \\
\hline & \multirow{4}{*}{ Y10 } & Initial & $0.02 \pm 0.01$ & $7.73 \pm 1.45$ & $3.90 \pm 0.11$ & $96.26 \pm 1.05$ & $98.69 \pm 1.05$ \\
\hline & & 3 month & $0.02 \pm 0.02$ & $5.96 \pm 1.45$ & $3.36 \pm 0.14$ & $94.31 \pm 3.18$ & $94.97 \pm 0.61$ \\
\hline & & 6 month & $0.04 \pm 0.02$ & $4.82 \pm 0.53$ & $3.23 \pm 0.11$ & $92.29 \pm 2.08$ & $91.48 \pm 1.12$ \\
\hline & & Initial & $0.01 \pm 0.01$ & $13.40 \pm 0.95$ & $1.01 \pm 0.01$ & $98.20 \pm 3.39$ & $100.71 \pm 1.22$ \\
\hline \multirow{15}{*}{$\begin{array}{c}\text { Mountaneous } \\
\text { B }\end{array}$} & \multirow[t]{3}{*}{ D10 } & 3 month & $0.01 \pm 0.00$ & $10.17 \pm 0.88$ & $0.99 \pm 0.04$ & $98.12 \pm 2.39$ & $100.66 \pm 0.88$ \\
\hline & & 6 month & $0.03 \pm 0.01$ & $9.43 \pm 0.62$ & $0.94 \pm 0.03$ & $93.17 \pm 1.19$ & $96.27 \pm 0.05$ \\
\hline & & Initial & $0.13 \pm 0.02$ & $7.15 \pm 0.43$ & $0.58 \pm 0.02$ & $99.11 \pm 3.36$ & $100.62 \pm 1.37$ \\
\hline & \multirow[t]{3}{*}{$\mathrm{T} 20$} & 3 month & $0.14 \pm 0.02$ & $6.93 \pm 0.40$ & $0.54 \pm 0.03$ & $99.07 \pm 2.43$ & $100.28 \pm 0.43$ \\
\hline & & 6 month & $0.23 \pm 0.02$ & $6.68 \pm 0.53$ & $0.53 \pm 0.05$ & $96.38 \pm 1.43$ & $96.03 \pm 0.17$ \\
\hline & & Initial & $0.12 \pm 0.02$ & $4.82 \pm 0.69$ & $7.87 \pm 0.47$ & $74.00 \pm 5.29$ & $100.28 \pm 0.37$ \\
\hline & \multirow[t]{2}{*}{ K20 } & 3 month & $0.26 \pm 0.02$ & $4.78 \pm 0.75$ & $7.20 \pm 0.21$ & $70.53 \pm 6.29$ & $99.24 \pm 1.31$ \\
\hline & & 6 month & $0.34 \pm 0.02$ & $4.47 \pm 0.39$ & $6.48 \pm 0.36$ & $63.26 \pm 3.72$ & $92.43 \pm 1.07$ \\
\hline & \multirow{4}{*}{ Y10 } & Initial & $0.02 \pm 0.01$ & $8.52 \pm 1.32$ & $3.82 \pm 0.12$ & $95.56 \pm 3.92$ & $98.62 \pm 1.03$ \\
\hline & & 3 month & $0.03 \pm 0.01$ & $6.33 \pm 1.79$ & $3.37 \pm 0.15$ & $93.94 \pm 2.61$ & $94.34 \pm 1.21$ \\
\hline & & 6 month & $0.04 \pm 0.02$ & $4.32 \pm 0.51$ & $3.28 \pm 0.13$ & $91.13 \pm 2.25$ & $91.78 \pm 0.50$ \\
\hline & & Initial & $0.02 \pm 0.00$ & $11.96 \pm 1.42$ & $1.00 \pm 0.02$ & $98.49 \pm 2.17$ & $100.68 \pm 0.68$ \\
\hline & \multirow[t]{3}{*}{ D10 } & 3 month & $0.01 \pm 0.01$ & $10.54 \pm 0.79$ & $0.98 \pm 0.02$ & $97.76 \pm 2.23$ & $100.28 \pm 1.07$ \\
\hline & & 6 month & $0.04 \pm 0.03$ & $9.13 \pm 0.75$ & $0.95 \pm 0.03$ & $92.19 \pm 2.94$ & $96.28 \pm 0.93$ \\
\hline & & Initial & $0.14 \pm 0.02$ & $7.32 \pm 0.34$ & $0.60 \pm 0.05$ & $98.59 \pm 2.41$ & \pm 1.55 \\
\hline \multirow{10}{*}{$\begin{array}{l}\text { Hills and Lake } \\
\text { A }\end{array}$} & \multirow[t]{3}{*}{$\mathrm{T} 20$} & 3 month & $0.16 \pm 0.03$ & $7.30 \pm 0.52$ & $0.50 \pm 0.05$ & $97.86 \pm 2.51$ & $100.45 \pm 0.83$ \\
\hline & & 6 month & $0.23 \pm 0.01$ & $7.29 \pm 0.21$ & $0.49 \pm 0.02$ & $96.81 \pm 2.54$ & $95.46 \pm 0.43$ \\
\hline & & Initial & $0.15 \pm 0.01$ & $4.47 \pm 0.42$ & $7.57 \pm 0.09$ & $77.79 \pm 5.77$ & $99.14 \pm 1.02$ \\
\hline & \multirow[t]{3}{*}{$\mathrm{K} 20$} & 3 month & $0.24 \pm 0.02$ & $4.21 \pm 0.38$ & $7.18 \pm 0.13$ & $71.14 \pm 6.34$ & $99.09 \pm 1.94$ \\
\hline & & & 0.07 & $4.20 \pm 0.47$ & $6.99 \pm 0.07$ & $64.44 \pm 5.23$ & 0.41 \\
\hline & & Initial & $0.03 \pm 0.02$ & $8.09 \pm 1.08$ & $3.90 \pm 0.31$ & $96.70 \pm 2.01$ & $98.68 \pm 0.72$ \\
\hline & \multirow[t]{3}{*}{ Y10 } & 3 month & $0.03 \pm 0.02$ & $6.05 \pm 1.50$ & $3.57 \pm 0.22$ & $94.02 \pm 1.33$ & $94.40 \pm 0.70$ \\
\hline & & 6 month & $0.06 \pm 0.00$ & $5.34 \pm 0.51$ & $3.20 \pm 0.07$ & $92.34 \pm 3.13$ & $92.69 \pm 0.21$ \\
\hline & & Initial & $0.01 \pm 0.01$ & $12.32 \pm 0.86$ & $0.98 \pm 0.02$ & $98.16 \pm 1.76$ & $101.02 \pm 1.18$ \\
\hline & \multirow[t]{3}{*}{ D10 } & 3 month & $0.01 \pm 0.00$ & $10.96 \pm 1.05$ & $0.97 \pm 0.02$ & $97.72 \pm 2.24$ & $100.85 \pm 0.62$ \\
\hline \multirow{13}{*}{$\begin{array}{l}\text { Hills and Lake } \\
\text { B }\end{array}$} & & 6 month & $0.03 \pm 0.01$ & $9.63 \pm 0.61$ & $0.96 \pm 0.02$ & $93.10 \pm 1.67$ & $94.94 \pm 1.25$ \\
\hline & & Initial & $0.13 \pm 0.03$ & $7.24 \pm 0.49$ & $0.60 \pm 0.03$ & $98.83 \pm 2.02$ & $100.87 \pm 1.91$ \\
\hline & $\mathrm{T} 20$ & 3 month & $0.17 \pm 0.05$ & $7.21 \pm 0.56$ & $0.55 \pm 0.04$ & $97.62 \pm 2.35$ & $100.54 \pm 0.72$ \\
\hline & & 6 month & $0.23 \pm 0.04$ & $7.16 \pm 0.40$ & $0.50 \pm 0.05$ & $97.07 \pm 3.01$ & $94.68 \pm 1.72$ \\
\hline & & Initial & $0.13 \pm 0.00$ & $4.54 \pm 0.38$ & $7.26 \pm 1.18$ & $74.55 \pm 6.87$ & $99.77 \pm 1.76$ \\
\hline & $\mathrm{K} 20$ & 3 month & $0.25 \pm 0.00$ & $4.24 \pm 0.68$ & $7.08 \pm 0.32$ & $70.83 \pm 5.34$ & $99.17 \pm 0.54$ \\
\hline & & 6 month & $0.32 \pm 0.03$ & $4.18 \pm 0.36$ & $6.45 \pm 0.11$ & $65.52 \pm 5.47$ & $94.11 \pm 1.11$ \\
\hline & & Initial & $0.03 \pm 0.02$ & $8.22 \pm 1.67$ & $4.17 \pm 0.32$ & $96.36 \pm 0.94$ & $99.97 \pm 1.90$ \\
\hline & Y10 & 3 month & $0.03 \pm 0.02$ & $6.35 \pm 1.58$ & $3.58 \pm 0.35$ & $94.45 \pm 0.72$ & $96.68 \pm 0.98$ \\
\hline & & 6 month & $0.05 \pm 0.02$ & $3.42 \pm 0.41$ & $3.30 \pm 0.12$ & $91.09 \pm 2.89$ & $92.49 \pm 0.76$ \\
\hline & & Initial & $0.02 \pm 0.01$ & $11.99 \pm 0.99$ & $1.01 \pm 0.03$ & $98.86 \pm 2.00$ & $100.82 \pm 0.47$ \\
\hline & D10 & 3 month & $0.01 \pm 0.00$ & $10.25 \pm 0.76$ & $0.96 \pm 0.04$ & $98.44 \pm 1.57$ & $100.67 \pm 0.60$ \\
\hline & & 6 month & $0.04 \pm 0.04$ & $8.47 \pm 0.41$ & $0.90 \pm 0.04$ & $93.55 \pm 1.31$ & $95.39 \pm 0.22$ \\
\hline
\end{tabular}


Table IIIb. Stability study of simvastatin generic tablets after six months

\begin{tabular}{|c|c|c|c|c|c|c|c|}
\hline \multirow[b]{2}{*}{ Location } & \multirow[b]{2}{*}{$\begin{array}{c}\text { Tablet } \\
\text { code }\end{array}$} & \multirow[b]{2}{*}{$\begin{array}{c}\text { Storage } \\
\text { Condition }\end{array}$} & \multicolumn{5}{|c|}{ Parameter } \\
\hline & & & $\begin{array}{c}\text { Friability } \\
(\%)\end{array}$ & $\begin{array}{l}\text { Hardness } \\
\text { (kgf) }\end{array}$ & $\begin{array}{c}\text { Disintegration } \\
\text { time (min) }\end{array}$ & $\begin{array}{c}\text { Dissolution } \\
(\%) \\
\end{array}$ & $\begin{array}{l}\text { Simvastatin } \\
\text { content }(\%)\end{array}$ \\
\hline \multirow{12}{*}{$\begin{array}{l}\text { Hills and } \\
\text { Lake B }\end{array}$} & \multirow{3}{*}{$\mathrm{T} 20$} & Initial & $0.13 \pm 0.03$ & $7.24 \pm 0.49$ & $0.60 \pm 0.03$ & $98.83 \pm 2.02$ & $100.87 \pm 1.91$ \\
\hline & & 3 month & $0.17 \pm 0.05$ & $7.21 \pm 0.56$ & $0.55 \pm 0.04$ & $97.62 \pm 2.35$ & $100.54 \pm 0.72$ \\
\hline & & 6 month & $0.23 \pm 0.04$ & $7.16 \pm 0.40$ & $0.50 \pm 0.05$ & $97.07 \pm 3.01$ & $94.68 \pm 1.72$ \\
\hline & \multirow{3}{*}{ K20 } & Initial & $0.13 \pm 0.00$ & $4.54 \pm 0.38$ & $7.26 \pm 1.18$ & $74.55 \pm 6.87$ & $99.77 \pm 1.76$ \\
\hline & & 3 month & $0.25 \pm 0.00$ & $4.24 \pm 0.68$ & $7.08 \pm 0.32$ & $70.83 \pm 5.34$ & $99.17 \pm 0.54$ \\
\hline & & 6 month & $0.32 \pm 0.03$ & $4.18 \pm 0.36$ & $6.45 \pm 0.11$ & $65.52 \pm 5.47$ & $94.11 \pm 1.11$ \\
\hline & \multirow{4}{*}{ Y10 } & Initial & $0.03 \pm 0.02$ & $8.22 \pm 1.67$ & $4.17 \pm 0.32$ & $96.36 \pm 0.94$ & $99.97 \pm 1.90$ \\
\hline & & 3 month & $0.03 \pm 0.02$ & $6.35 \pm 1.58$ & $3.58 \pm 0.35$ & $94.45 \pm 0.72$ & $96.68 \pm 0.98$ \\
\hline & & 6 month & $0.05 \pm 0.02$ & $3.42 \pm 0.41$ & $3.30 \pm 0.12$ & $91.09 \pm 2.89$ & $92.49 \pm 0.76$ \\
\hline & & Initial & $0.02 \pm 0.01$ & $11.99 \pm 0.99$ & $1.01 \pm 0.03$ & $98.86 \pm 2.00$ & $100.82 \pm 0.47$ \\
\hline & \multirow[t]{3}{*}{ D10 } & 3 month & $0.01 \pm 0.00$ & $10.25 \pm 0.76$ & $0.96 \pm 0.04$ & $98.44 \pm 1.57$ & $100.67 \pm 0.60$ \\
\hline & & 6 month & $0.04 \pm 0.04$ & $8.47 \pm 0.41$ & $0.90 \pm 0.04$ & $93.55 \pm 1.31$ & $95.39 \pm 0.22$ \\
\hline \multirow{12}{*}{ Lowlands A } & & Initial & $0.14 \pm 0.03$ & $7.16 \pm 0.44$ & $0.60 \pm 0.06$ & $100.70 \pm 2.10$ & $100.86 \pm 1.37$ \\
\hline & \multirow{2}{*}{$\mathrm{T} 20$} & 3 month & $0.17 \pm 0.07$ & $7.03 \pm 0.34$ & $0.56 \pm 0.05$ & $97.33 \pm 3.93$ & $100.49 \pm 0.31$ \\
\hline & & 6 month & $0.21 \pm 0.01$ & $6.85 \pm 0.44$ & $0.50 \pm 0.03$ & $94.88 \pm 1.85$ & $95.12 \pm 0.78$ \\
\hline & \multirow{4}{*}{ K20 } & Initial & $0.16 \pm 0.00$ & $4.56 \pm 0.43$ & $7.67 \pm 0.87$ & $76.59 \pm 6.91$ & $100.86 \pm 0.62$ \\
\hline & & 3 month & $0.24 \pm 0.02$ & $4.28 \pm 0.44$ & $7.00 \pm 0.17$ & $72.12 \pm 3.18$ & $100.64 \pm 0.12$ \\
\hline & & 6 month & $0.32 \pm 0.06$ & $4.03 \pm 0.53$ & $6.46 \pm 0.11$ & $61.70 \pm 4.67$ & $93.95 \pm 0.90$ \\
\hline & & Initial & $0.02 \pm 0.01$ & $8.08 \pm 1.18$ & $4.00 \pm 0.14$ & $96.53 \pm 2.27$ & $99.08 \pm 1.42$ \\
\hline & \multirow{3}{*}{ Y10 } & 3 month & $0.02 \pm 0.01$ & $6.32 \pm 1.63$ & $3.41 \pm 0.08$ & $92.03 \pm 2.11$ & $95.24 \pm 1.68$ \\
\hline & & 6 month & $0.05 \pm 0.03$ & $5.60 \pm 0.66$ & $3.26 \pm 0.11$ & $90.63 \pm 2.17$ & $93.53 \pm 0.51$ \\
\hline & & Initial & $0.02 \pm 0.01$ & $11.99 \pm 0.86$ & $1.00 \pm 0.04$ & $99.49 \pm 1.97$ & $100.67 \pm 1.32$ \\
\hline & \multirow[t]{3}{*}{ D10 } & 3 month & $0.01 \pm 0.01$ & $10.28 \pm 0.34$ & $0.98 \pm 0.04$ & $98.72 \pm 1.03$ & $100.37 \pm 0.77$ \\
\hline & & 6 month & $0.04 \pm 0.04$ & $9.99 \pm 0.59$ & $0.93 \pm 0.04$ & $92.64 \pm 1.96$ & $94.94 \pm 1.72$ \\
\hline \multirow{12}{*}{ Lowlands B } & & Initial & $0.13 \pm 0.02$ & $7.09 \pm 0.54$ & $0.56 \pm 0.05$ & $100.37 \pm 2.05$ & $101.13 \pm 0.84$ \\
\hline & \multirow[t]{3}{*}{$\mathrm{T} 20$} & 3 month & $0.15 \pm 0.03$ & $6.95 \pm 0.38$ & $0.50 \pm 0.02$ & $98.80 \pm 3.45$ & $100.80 \pm 0.60$ \\
\hline & & 6 month & $0.23 \pm 0.02$ & $6.90 \pm 0.57$ & $0.49 \pm 0.04$ & $95.28 \pm 1.40$ & $95.49 \pm 0.73$ \\
\hline & & Initial & $0.15 \pm 0.03$ & $4.94 \pm 0.24$ & $7.55 \pm 1.04$ & $73.84 \pm 5.60$ & $99.82 \pm 1.36$ \\
\hline & \multirow[t]{3}{*}{$\mathrm{K} 20$} & 3 month & $0.26 \pm 0.03$ & $4.60 \pm 0.88$ & $7.28 \pm 0.09$ & $71.49 \pm 2.86$ & $99.57 \pm 0.60$ \\
\hline & & 6 month & $0.31 \pm 0.07$ & $4.53 \pm 0.44$ & $6.52 \pm 0.16$ & $61.64 \pm 3.15$ & $93.48 \pm 0.49$ \\
\hline & & Initial & $0.01 \pm 0.00$ & $8.75 \pm 1.52$ & $4.10 \pm 0.17$ & $96.72 \pm 1.89$ & $99.35 \pm 0.94$ \\
\hline & \multirow[t]{3}{*}{ Y10 } & 3 month & $0.02 \pm 0.01$ & $6.17 \pm 0.67$ & $3.36 \pm 0.29$ & $92.21 \pm 2.11$ & $95.10 \pm 1.40$ \\
\hline & & 6 month & $0.03 \pm 0.03$ & $5.07 \pm 0.71$ & $3.16 \pm 0.23$ & $90.61 \pm 4.94$ & $93.11 \pm 0.42$ \\
\hline & & Initial & $0.01 \pm 0.00$ & $13.30 \pm 1.33$ & $1.01 \pm 0.02$ & $99.76 \pm 2.09$ & $100.36 \pm 0.49$ \\
\hline & \multirow[t]{2}{*}{ D10 } & 3 month & $0.01 \pm 0.01$ & $11.05 \pm 0.53$ & $0.99 \pm 0.02$ & $98.09 \pm 1.43$ & $99.30 \pm 1.02$ \\
\hline & & 6 month & $0.03 \pm 0.02$ & $10.24 \pm 0.93$ & $0.96 \pm 0.02$ & $95.60 \pm 2.51$ & $94.82 \pm 0.63$ \\
\hline
\end{tabular}

Table IV. Levene Test

\begin{tabular}{|c|c|c|c|c|}
\hline \multicolumn{5}{|c|}{ Levene's Test of Equality of Error Variances ${ }^{a}$} \\
\hline & $\mathbf{F}$ & df1 & df2 & Sig. \\
\hline DT & 6.384 & 71 & 144 & .000 \\
\hline Friability & 3.350 & 71 & 144 & .000 \\
\hline Hardness & 3.328 & 71 & 144 & .000 \\
\hline Assay & 1.814 & 71 & 144 & .001 \\
\hline Dissolution Rate & 2.050 & 71 & 144 & .000 \\
\hline
\end{tabular}




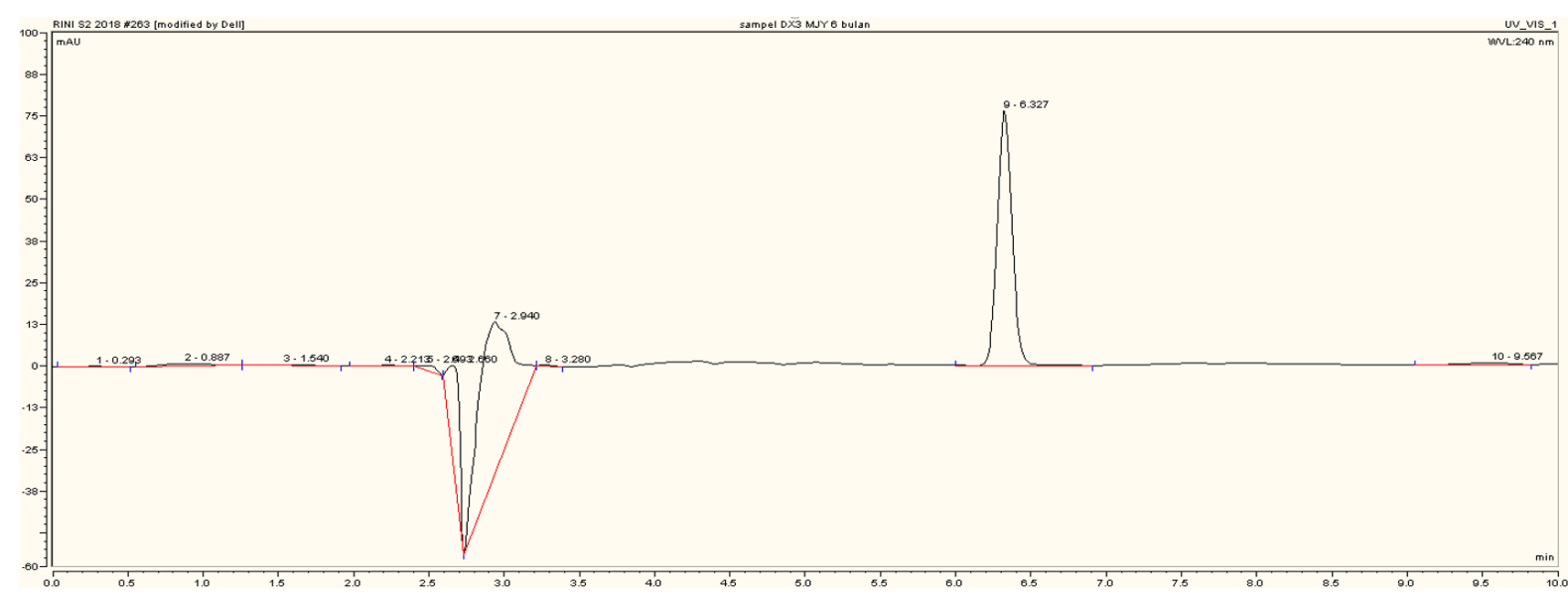

Figure 3. Chromatogram SIM D10 Lowlands A at 6 Month

\section{UV Methods \\ Selectivity (Specificity)}

The results of the specificity test showed that the absorption spectrum of simvastatin tablets was the same as the pure standard absorption spectrum, there was no interference from the tablet matrix. The criteria for specificity are thus met and the specification of this method can be considered suitable.

\section{Accuracy and precision}

The percentage of recovery obtained is in the range of $99.30-100.03 \%$ and is considered acceptable. The \% RSD value calculated at each concentration shows an acceptable repeatability (range RSD $0.61-0.94 \%$, RSD $<2 \%$ ).

\section{Linearity}

The equation of the line obtained is $\mathrm{y}=$ $0.0613 x+0.0005$ with $r 2=0.9976$. These results indicate that the linearity of this method has met the specifications.

\section{Assay}

Drug content was the main aspect of drug quality assessment. This is important to ensure that the percentage of active ingredient available in the product meet the amount stated on the product label (Bakre \& Taiwo, 2015). Tests are usually published in pharmacopoeia monographs for each active ingredient. According to FDA guidelines, the percentage of active ingredient in a product should be within the range of $\pm 5 \%$ of the claim label at the beginning of release and $\pm 10 \%$ during the shelf life (FDA, 2005). According to Pharmacopoeia
Indonesia ed. $\mathrm{V}$, simvastatin tablets should contain no less than $90 \%$ and no more than $110.0 \%$ of the amount indicated on the label (Farmakope, 2014). Based on the analysis done, the initial content of simvastatin in the four tablet samples ranged between 98 - 101\%.

After 3 months of storage, there was a reduction in content in all samples. For SIM T20, SIM K20, and SIM D10, the difference was between 0.5 - 1\%. However, SIM Y10 had a greater reduction level margin ( $\pm 3-5 \%$ ). SIM T20 and SIM K20 packaging were Alu-Alu strip packaging that withstood the entry of water vapor and oxygen than PVC-Alu blister packaging (Allinson et al., 2001). The tablet coating material used in the formulation of SIM D10 and SIM Y10 tablets could also influence the drug content reduction, which translated into a bigger reduction percentage in SIM Y10 than SIM D10. After six months of storage, all samples showed a reduction in drug content, but still met the level requirements of $90 \%-110 \%$ as stated in the Pharmacopoeia Indonesia ed. V (USP, 2011) (Figure 3).

In a previous study by Hapsari (2016), two generics and generics with trademark (nongenerics) $10 \mathrm{mg}$ simvastatin tablets were taken from one pharmacy facility in East Jakarta. The samples had the same expiry date (2018). The assay showed that one of the generic tablet has a much lower drug concentration than the required specification (87\%-90\%) However, the duration and conditions of tablet storage were not mentioned, hence it can be assumed that the storage condition is not controlled and is representing the normal daily storage situation (Hapsari, 2016). 




Figure 4. Spectrum SIM T20 Mountainous B at 0 Month

In another study from Brazil, only 14 out of 30 batches of simvastatin $20 \mathrm{mg}$ capsules were found to comply with pharmacopeia quality standards (Marques-Marinho et al., 2011) and 6 out of 18 simvastatin $40 \mathrm{mg}$ capsules had an assay content of between 4 - 87\% (Markman et al., 2010). As Brazil has a tropical climate with hot and humid weather, this could be an important factor that influences the stability of the tablets during storage (Bott \& Oliveira, 2007).

The effects of storage on drug quality in hot and humid tropical climates had been widely observed by previous studies, including amoxicillin-clavulanic acid in Cambodia (Khan et al., 2013), antihypertensive drugs in Rwanda (Twagirumukiza et al., 2009), anti-malarial drugs in Southeast Asia, and Sub-Saharan Africa (Nayyar et al., 2012). Based on these studies, the regulation of temperature and humidity as well as the protection of drugs from moisture are among the important factors to be considered for the storage of drugs in tropical climates. The most common and simple way to protect moisture-sensitive drugs is using a packaging protector. However, many packaging materials used are permeable to moisture (Allinson et al., 2001). Humidity could vary widely during the shelf life of the drug product, and the packaging material must be able to protect products from such variations. The method frequently used is inserting desiccants into the packaging to absorb moisture (Lehto \& Erling, 2007). This method can be applied in pharmaceutical facilities for medicines that are sensitive to moisture. The drug can be stored in a closed container equipped with desiccant (silica gel). For indoor drug storage, the medicine room at pharmaceutical facilities should provide a special room equipped with air conditioning, humidifier, and measuring devices for temperature and humidity control.

\section{Dissolution}

According to Pharmacopoeia Indonesia ed. $\mathrm{V}$, simvastatin must dissolve at least $75 \%$ (Q) within $30 \mathrm{~min}$ of the amount stated on the label (Farmakope, 2014). The dissolution test results obtained at month 0 for samples SIM T20, SIM Y10, and SIM D10 met the requirements, with $95-100 \%$ of the stated label dissolved within the stipulated time. Meanwhile, the dissolution test conducted for SIM K20 tablets were outside of the specifications, thus another set of dissolution test was conducted. The test results from 12 tablets of SIM K20 tablets met the S2 criteria (average of 12 units $\geq Q$ and no dosage unit was smaller than $Q$ $15 \%)$ for 2 samples (77.79\%, and $76.59 \%)$. However, the other samples did not meet the criteria of S1 and S2 (Figure 4).

Dissolution may be affected by various formulation factors, such as dosage form, additives, and the manufacturing process. The choice of disintegrant will influence the bond strength between particles in a tablet, which will in turn affect the ease of fluid penetration into the tablet (Markl \& Zeitler, 2017). The test results for the months 3 and 6 showed reduction in percent dissolution for all samples. In month 3 , the dissolution of SIM T20, SIM Y10, and SIM D10 met the Q requirement of 75\% (dissolution: 92\% 99\%), but SIM K20 did not meet the S1 and S2 criteria for 12 tablets testing (dissolution: 70\% $72 \%$ ). In month 6, SIM K20 also did not meet the 
dissolution specifications for 6 months storage (dissolution: 60.7\% - 65.5\%), but SIM T20, SIM Y10, SIM D10 samples showed a good dissolution profile (dissolution: 90\% - 97\%). The reduction in percent dissolution was expected, as storage in high humidity area may lead to the reduction in overall simvastatin concentration available in the product (ASEAN, 2017; Karbane et al., 2014) (Table III).

\section{Statistical analysis}

Statistical analysis used the multivariate ANOVA (MANOVA) method by comparing the effect of different samples, packaging, place, and storage time on the physical and chemical parameters of the tested tablets. All statistical analysis is available in the Supplementary file. The results of the multivariate test showed that there was a significant effect of the independent variables on all dependent variables. The p-value shows $<0.05$, so it is significant at the $95 \%$ confidence level (Table III), homogeneity test of variance (Levene test) of all variables will have the same variance if the value of sig. $>0.05$. The results of the Levene test however showed that all dependent variables do have different variances as the significance value calculated is $<0.05$.

The MANOVA test is deemed to be significant if the $p$ value is $<0.05$. The analysis done on the subject effects test showed the value of significance is 0.000 . Thus, the results of the statistical test can be explained as follows:

The place does not significantly affect the value of disintegration time, friability, hardness, content, dissolution as the $\mathrm{p}$ value $>0.05$. Differences in storage locations based on mountainous, hill and lake zones, and lowlands did not affect the physical and chemical quality parameters of generic simvastatin tablets. All samples experienced a decrease in quality after being stored for 6 months. This is because all locations have the same tropical climate despite different altitudes.

The type of sample significantly affects the value of disintegration time, friability, hardness, content, dissolution ( $p$ value $=0.000$ ). The dosage forms (coated/uncoated tablets) significantly affect the disintegration time, friability, hardness, drug content and dissolution time ( $p$ value $=0.000$ ). The different types of samples and dosage forms affect the physical and chemical quality parameters of generic simvastatin tablets. The samples of SIM T20 and SIM D10 have better physical and chemical quality parameters than the other two samples after being stored for 6 months. This is due to the different formulations of each sample.

Packaging types significantly affect the value of disintegration time, friability, hardness, drug content and dissolution time $(\mathrm{p}$ value $=0.000)$. After 6 months of storage, tablets in blister packs experienced a decrease in physical qualities such as hardness and disintegration time, more than tablets packed in strip packaging.

Storage time significantly affect the value of disintegration time, friability, hardness, drug content and dissolution time ( $\mathrm{p}$ value $=0.000$ ) . Storage for 6 months in a drug room that has not met the requirements causes a decrease in the physical and chemical quality parameters of generic simvastatin tablets.

\section{CONCLUSION}

This study observes the effects of uncontrolled temperature and humidity during storage on the characteristics of four simvastatin generic tablets. When a highly sensitive drug is stored in a common drug room, the result is a reduction in quality, such as disintegration, friability, hardness, content, and dissolution. This must be taken into consideration when formulating such drug, as factors such as coating a tablet and choosing a suitable packaging material may help to ensure the stability of the drug product during its shelf life, despite being subjected to challenging environment such as high humidity.

\section{ACKNOWLEDGEMENT}

We gratefully acknowledge the Rector of Universitas Padjadjaran for funding this project through the Grant of Academic Leadership Grants 2021 no. 1959/UN6.3.1/PT.00/2021 from Universitas Padjadjaran.

\section{REFERENCES}

Ahmad, I., \& Shaikh, R. H. (1994). Effect of temperature and humidity on hardness and friability of packaged paracetamol tablet formulations. Pak. J. Pharm. Sci., 7(2), 69-78.

Akbuga, J., \& Gürsoy, A. (1987). The Effect of Moisture Sorption and Desorption on Furosemide Tablet Properties. Drug Dev. Indus. Pharm., 13(9-11), 1827-1845. https://doi.org/10.3109/03639048709068 $\underline{695}$

Allen, L. V., Jr. (2013). Basics of compounding: potency and stability testing. Int. J. Pharm. Compd., 17(3), 220-224. 
Allinson, J. G., Dansereau, R. J., \& Sakr, A. (2001). The effects of packaging on the stability of a moisture sensitive compound. Int. J. Pharm., 221(1-2), 49-56. https://doi.org/10.1016/s03785173(01)00670-6

Ammann, C. (2011). Stability studies needed to define the handling and transport conditions of sensitive pharmaceutical or biotechnological products. AAPS PharmSciTech, 12(4), 1264-1275. https://doi.org/10.1208/s12249-0119684-0

ASEAN. (2017). ASEAN Guidelines nn Stability Study and Shelf-Life of Traditional Medicines. The Association of Southeast Asian Nations (ASEAN). Retrieved 09/09/2021 from https://asean.org/wpcontent/uploads/2017/09/ASEANGuidelines-on-Stability-and-Shelf-Life-TMV1.0-with-disclaimer.pdf

Bajaj, S., Singla, D., \& akhuja, N. S. (2012). Stability Testing of Pharmaceutical Products. J. Appl. Pharmaceu. Sci., 02(03), 129-138. https://doi.org/10.7324/JAPS.2012.2322

Bakre, L., \& Taiwo, Y. (2015). Studies of the effect of storage conditions on some Pharmaceutical Parameters of Pharmaceutical Powders and Tablets. Dhaka Univ. J. Pharmaceu. Sci., 14(2), 147-151. https://doi.org/10.3329/dujps.v14i2.2850 $\underline{3}$

Bharath Raman, H. M., Patrick Ball. (2017). Pharmaceuticals in the tropics: A quantitative study measuring changes in quantity of the active ingredient and microbiological growth. J. Appl. Pharmaceu. Sci.(9), 160-170. http://japsonline.com/abstract.php?article id=2420

BIO Intelligence Service, B. (2013). Study on the environmental risks of medicinal products (Final Report prepared for Executive Agency for Health and Consumers, Issue. https://ec.europa.eu/health/sites/default/f iles/files/environment/study environment. pdf

Bott, R. F., \& Oliveira, W. P. (2007). Storage conditions for stability testing of pharmaceuticals in hot and humid regions. Drug. Dev. Ind. Pharm., 33(4), 393-401. https://doi.org/10.1080/03639040600975 $\underline{022}$
Chaturvedi, H., Garg, A., \& US., R. (2017). Postcompression evaluation parameters for tablets-an overview. Eur. J. Pharm. Med. Res., 37(1), 526-530.

Chen, W. L., Guo, D. W., Shen, Y. Y., Guo, S. R., \& Ruan, K. P. (2012). Effects of highly hygroscopic excipients on the hydrolysis of simvastatin in tablet at high relative humidity. Indian J. Pharm. Sci., 74(6), 527-534. https://doi.org/10.4103/0250474x.110587

Chiang, E. (2013). Measuring Tablet Hardness: A Primer. Pharm. Technol., 37(1), 1-3.

Devu, S., Gupta, A., Srinivas, K., Gupta, R., \& Semwal, V. (2012). Chromatography Development and Validation of Stability Indicating RPUPLC Method for Simultaneous Determination in Fixed Dose Combination of Ezetimibe and. J. Chromatogr. Sep. Tech. , 3(1), 1-7.

Dugar, R. P., Gupta, P., \& Dave, R. H. (2015). Effect of relative humidity on acetaminophen tablet properties prepared by different techniques using polyvinylpyrrolidine derivatives as binder. Inter. J. Pharmaceu. Sci. Res., 6(11), 4629.

Eiland, L. S., \& Luttrell, P. K. (2010). Use of statins for dyslipidemia in the pediatric population. The journal of pediatric pharmacology and therapeutics : JPPT : the official journal of PPAG, 15(3), 160-172. https://pubmed.ncbi.nlm.nih.gov/2247780 $\underline{8}$

https://www.ncbi.nlm.nih.gov/pmc/articles/PMC 3018249/

EMA, E. M. A. (1995). ICH Q2 (R1) Validation of analytical procedures: text and methodology. European Medicine Agency. Retrieved 10/11/2019 from https://www.ema.europa.eu/en/ich-q2-r1validation-analytical-procedures-textmethodology

Farmakope, N. F. a. D. A. (2014). Farmakope Indonesia (Vol. 5). National Food and Drug Agency.

FDA. (2005). ASEAN guideline on stability study of drug product. In a. c. c. f. s. a. q.-p. p. w. g. (ACCSQ-PPWG) (Ed.). Jakarta: FDA.

FDA, F. D. A. (2015). Analytical Procedures and Methods Validation for Drugs and Biologics: Guidance for Industry. Food and Drug Administration (FDA). Retrieved 10/11/2019 from https://www.fda.gov/files/drugs/publishe 
d/Analytical-Procedures-and-MethodsValidation-for-Drugs-and-Biologics.pdf

Gupta, M. M., \& Gupta, M. (2016). Comparative InVitro Quality Control Testing of Different Brands of Paracetamol Tablets Available In The Trinidad \& Tobago, West Indies. Int. J. Pharm. Sci .Res., 2830-2836.

Hapsari, Y. (2016). Quality Comparison of simvastatin tablets BPJS e-catalogue and non BPJS e-catalogue [Thesis, UIN]. Jakarta. https://repository.uinjkt.ac.id/dspace/bitst ream/123456789/33426/1/Yunnica\%20Sr i\%20Hapsari-FKIK.pdf

Jemal, M., Ouyang, Z., \& Powell, M. L. (2000). Directinjection LC-MS-MS method for highthroughput simultaneous quantitation of simvastatin and simvastatin acid in human plasma. J. Pharm. Biomed. Anal., 23(2-3), 323-340. https://doi.org/10.1016/s07317085(00)00309-5

Kapuganti, A., Gandhi, B., Raju, V., Sumanth, K., Kagitapurapu, V., Srinivas, K., \& Harika, P. (2016). Development and Validation of Stability Indicating RP-HPLC Method for Simultaneous Estimation of Ramipril, Aspirin and Simvastatin in Bulk and Pharmaceutical Dosage Form. Asian J. Biomed. Pharm. Sci., 6(1), 14-20.

Karbane, M., RamLi, Y., Al-Kamarany, M., Bouchfra, H., Radi, M., Karrouchi, K., Cherrah, Y., Bouklouze, A., \& Azougagh, M. (2014). Development and validation of HPLC dissolution assay of simvastatin tablets under normal and accelerated conditions. J. . Chem. Pharmaceu. Res., 6(6), 886-893.

Khan, M. H., Hatanaka, K., Sovannarith, T., Nivanna, N., Casas, L. C. C., Yoshida, N., Tsuboi, H., Tanimoto, T., \& Kimura, K. (2013). Effects of packaging and storage conditions on the quality of amoxicillin-clavulanic acid - an analysis of Cambodian samples. BMC Pharmacol. Toxicol., 14, 33-33. https://doi.org/10.1186/2050-6511-14-33

Kulkarni, A. P., Shahnawaz, M., Zaheer, Z., \& Dehghan, M. H. (2012). Development and Validation of a Dissolution Method for Pioglitazone Tablets. Dissolution Technologies, 19(4), 36-45. https://doi.org/10.14227/DT190412P36

Kumar, D. A., Sujan, D. P., Vijayasree, V., \& Rao, J. V. L. N. S. (2009). Simultaneous Determination of Simvastatin and Ezetimibe in Tablets by HPLC. E-Journal Chem., 6, 626343. https://doi.org/10.1155/2009/626343
Lehto, V. P., \& Erling, I. (2007). An effective desiccant system to regulate the humidity inside the chambers of the solid dosage forms. Drug. Dev. Ind. Pharm., 33(11), 12331239.

https://doi.org/10.1080/03639040701377 $\underline{946}$

Lotfy, H. M., El Sanabary, H. F., El-Sherif, Z. A., \& ElBardicy, M. G. (2010). Stability study of simvastatin and pravastatin sodiumunder acidic hydrolytic conditions assessed by high performance liquid chromatography. Anal. Chem: An Ind. Journal, 9(1), 172-184.

Markl, D., \& Zeitler, J. A. (2017). A Review of Disintegration Mechanisms and Measurement Techniques. Pharmaceu. Res., 34(5), 890-917. https://doi.org/10.1007/s11095-0172129-z

Markman, B. E., Rosa, P. C., \& Koschtschak, M. R. (2010). Assessment of the quality of simvastatin capsules from compounding pharmacies. Rev. Saude Publica, 44(6), 10551062. https://doi.org/10.1590/s003489102010000600010

Marques-Marinho, F., José da Costa Zanon, C., Sakurai, E., Reis, I. A., Lima, A. A., \& ViannaSoares, C. D. (2011). Quality evaluation of simvastatin compounded capsules. Brazilian J. Pharm. Sci., 47(3), 495-502. https://doi.org/10.1590/S198482502011000300007

Melo, S. R., Homem-de-Mello, M., Silveira, D., \& Simeoni, L. A. (2014). Advice on Degradation Products in Pharmaceuticals: A Toxicological Evaluation. PDA J. Pharm. Sci. Tech., 68(3), 221-238. https://doi.org/10.5731/pdajpst.2014.009 $\underline{74}$

Mubengayi, C. K., RamLi, Y., Routaboul, C., Gilard, V., El Karbane, M., Cherrah, Y., MaletMartino, M., \& Essassi, E. M. (2016). Quality Evaluation of Diclofenac Formulations Manufactured in DR Congo. Pharm. Anal. Chem., 2(1), 1-6. https://doi.org/10.4172/2471$\underline{2698.1000112}$

Nayyar, G. M. L., Breman, J. G., Newton, P. N., \& Herrington, J. (2012). Poor-quality antimalarial drugs in southeast Asia and sub-Saharan Africa. The Lancet Infect. Dis., 12(6), 488-496. https://doi.org/10.1016/S1473$\underline{3099(12) 70064-6}$ 
Nogueira, F. H., Moreira-Campos, L. M., Santos, R. L., \& Pianetti, G. A. (2011). Quality of essential drugs in tropical countries: evaluation of antimalarial drugs in the Brazilian Health System. Rev. Soc. Bras. Med. Trop., 44(5), 582586. $\quad$ https://doi.org/10.1590/s0037$\underline{86822011000500010}$

Othman, G., \& Al-qadasi, F. (2016). Quality and Stability of Amoxicillin-Potassium Clavulanate Drugs Marketed in Yemen: Influence of Tropical Storage Conditions. J. Chem. Pharmaceu. Res., 8, 160-166.

Ramalingam, P., Bhaskar, V. U., Reddy, Y. P., \& Kumar, K. V. (2014). Stability-indicating RPHPLC Method for the Simultaneous Determination of Sitagliptin and Simvastatin in Tablets. Ind. J. Pharmaceu. Sci., 76(5), 407414.

https://pubmed.ncbi.nlm.nih.gov/2542575 $\underline{4}$

Rubinstein, M. H., \& Bodey, D. M. (1976). Disaggregation of Compressed Tablets. J. Pharmaceu. Sci., 65(12), 1749-1753. https://doi.org/https://doi.org/10.1002/jp s.2600651214

Seitz, J. A., \& Flessland, G. M. (1965). Evaluation of the physical properties of compressed tablets. I. Tablet hardness and friability. J. Pharmaceu. Sci., 54(9), 1353-1357. https://doi.org/10.1002/jps.2600540926

Shabir, G. A. (2003). Validation of highperformance liquid chromatography methods for pharmaceutical analysis. Understanding the differences and similarities between validation requirements of the US Food and Drug Administration, the US Pharmacopeia and the International Conference on Harmonization. J Chromatogr A, 987(1-2), 57-66. https://doi.org/10.1016/s0021$\underline{9673(02) 01536-4}$

Shafaat, K., Hussain, A., Kumar, B., Hasan, R., Prabhat, P., \& Yadav, V. (2013). An Overview: Storage of Pharmacuetical Products. World J. Pharm. Phramaceu. Sci, 2, 2499-2515.

Singh, A., Sharma, P., \& Malviya, R. (2011). Eco Friendly Pharmaceutical Packaging Material. World Appl. Sci. J., 14, 1703-1716.

Tembhare, E., Gupta, K. R., \& Umekar, M. J. (2019). An Approach to Drug Stability Studies and Shelf-life Determination. . Arch. Curr. Res. Inter., 19(1), 1-20. https://doi.org/10.9734/acri/2019/v19i13 $\underline{0147}$
Twagirumukiza, M., Cosijns, A., Pringels, E., Remon, J. P., Vervaet, C., \& Van Bortel, L. (2009). Influence of tropical climate conditions on the quality of antihypertensive drugs from Rwandan pharmacies. Am. J. Trop. Med. Hyg., 81(5), 776-781. https://doi.org/10.4269/ajtmh.2009.09$\underline{0109}$

USP. (2006). Material Safety Data Sheet Simvastatin Tablets. In USP (Ed.). New York: USP.

USP, U. S. P. t. e. (2011). The United States Pharmacopeial Convention. USP. Retrieved 03/09/2019 from https://www.usp.org/sites/default/files/us $\mathrm{p} /$ document/harmonization/genmethod/stage 6 monograph 25 feb 2011.p df

Waterman, K., \& MacDonald, B. (2010). ChemInform Abstract: Package Selection for Moisture Protection for Solid, Oral Drug Products. J. Pharmaceu. Sci., 99, 4437-4452. https://doi.org/10.1002/ips.22161

Waterman, K. C., \& MacDonald, B. C. (2010). Package selection for moisture protection for solid, oral drug products. J. Pharmaceu. Sci., 99(11), 4437-4452. https://doi.org/10.1002/jps.22161

World Health, O., \& Preparations, W. H. O. E. C. o. S. f. P. (2018a). Fifty-second report of the WHO Expert Committee on Specifications for Pharmaceutical Preparations. World Health Organization. https://apps.who.int/iris/handle/10665/2 $\underline{72452}$

World Health, O., \& Preparations, W. H. O. E. C. o. S. f. P. (2018b). Guide to good storage practices for pharmaceuticals. World Health Organization.

https://apps.who.int/iris/handle/10665/2 $\underline{72452}$ 